\title{
Are pest regulation and erosion alleviation services conflicting or synergistic? Lessons from Sahel pearl millet
}

\author{
Alain Ratnadass ${ }^{\mathrm{a}, \mathrm{b}, *}$, Hame Kadi-Kadi ${ }^{\mathrm{a}, \mathrm{c}}$, Halarou Salha ${ }^{\mathrm{a}}$, Abdou Mato ${ }^{\mathrm{a}}$, \\ Amadou Idrissa ${ }^{\mathrm{a}, \mathrm{d}}$, Sahabi Hamidine ${ }^{\mathrm{e}}$, Ilyassou Oumarou ${ }^{\mathrm{a}}$, Dougbedji Fatondji ${ }^{\mathrm{a}}$ \\ a ICRISAT, BP 12404 Niamey, Niger \\ b CIRAD-PERSYST, UPR HortSys, TA B-103/PS4, Montpellier F-34398, France \\ c INRAN CARRA/BP 60, Kollo, Niger \\ d Abdou Moumouni Univ., Fac. Agron., BP 10960 Niamey, Niger \\ e Doukoudoukou Seed Multiplication Center, Tahoua, Niger
}

\section{A R T I C L E I N F O}

\section{Article history:}

Received 31 May 2013

Received in revised form 22 January 2014

Accepted 23 January 2014

\section{Keywords:}

Coniesta ignefusalis

Heliocheilus albipunctella

Rhinyptia infuscata

Crop residue

Mulching

Wind erosion

\begin{abstract}
A B S T R A C T
From 2010 to 2011 in Niger, the effects of a wind erosion-alleviating practice, i.e. mulching pearl millet fields with crop residue, on populations of and damage induced by millet stem borer (MSB), head miner (MHM), and head scarab (MHS) were studied. Significant differences in the survival of MSB diapausing larvae in millet stems at the end of the dry season were found at both Sadore and Doukoudoukou. At Sadore, mean MSB larval survival in the treatment where stems were exported at harvest and stored on platforms (treatment 1 ) was 1.2/stem, i.e. significantly higher than in all other treatments. Survival was between 0.1 and 0.2 larva in treatments 2 (with millet stems left standing from harvest throughout the dry season) and 3 (with millet stems flattened toward the end of the dry season, four months after harvest). It was less than 0.1 larva in treatments 4 (with millet stems flattened in the middle of the dry season, two months after harvest) and 5 (with millet stems flattened at the beginning of the dry season, at harvest). At Doukoudoukou, mean MSB larval survival in treatment 1 was $0.14 /$ stem, i.e. significantly higher than in treatments 4 and 5 (0.02-0.03 larva), with intermediary findings obtained in treatments 2 and 3 (0.04-0.08 larva). The population and biomass of diapausing MHM pupae and of MHS larvae in the soil were low at both locations, and not affected by crop residue management. Thus, crop residue management whereby stems were left standing until the end of the dry season did not enhance control of millet head pests via increased predator activity, while it increased MSB survival in stems.
\end{abstract}

(c) 2014 Elsevier B.V. All rights reserved.

\section{Introduction}

In the Sahel, there is a major soil erosion problem due to winds at the time of the dry season to rainy season shift (Rajot et al., 2009). On sandy soils wind can also damage sown millet crops. Several management practices have been implemented or proposed to alleviate this erosion and thus contribute to soil conservation and pearl millet crop protection. In earlier studies conducted by the International Crops Research Institute for the Semi-Arid Tropics (ICRISAT) in Niger, borders of the perennial grass Andropogon gayanus were shown to efficiently protect millet against violent winds (Renard and Vandenbelt, 1990), although there were also contradictory reports (Michels et al., 1998).

\footnotetext{
* Corresponding author at: CIRAD-PERSYST, UPR HortSys, TA B-103/PS4, Montpellier F-34398 France. Tel.: +33 467593114.

E-mail address: alain.ratnadass@cirad.fr (A. Ratnadass).
}

ICRISAT's research also highlighted positive effects of mulching and leaving millet straw in fields after harvest to curb soil erosion (Michels et al., 1998) and analyzed the benefits of farmers measures to reduce wind erosion, including mulching (Bielders et al., 2004). On the other hand, several studies have highlighted the impact of millet crop (stem) residue management on the survival of diapausing millet stem borer (MSB=Coniesta ignefusalis) larvae and carry-over of the pest populations (Ajayi, 1990; Bouchard et al., 1993; Youm et al., 1996).

Pest control is sometimes considered an ecosystem service per se (Millennium Ecosystem Assessment, 2003). It contributes to food/biomass production, which is an essential service in terms of agroecosystem sustainability. We conducted trials in Niger from 2010 to 2011 to determine whether measures geared toward supporting ecosystem services of soil conservation, as well as pest regulation, were synergistic or conflicting. They were aimed at assessing the impact of millet crop residue management on the survival of the MSB and the millet head miner (MHM = Heliocheilus albipunctella), along with that of the millet head scarab beetle 
(MHS = Rhinyptia infuscata), another highly damaging pest of pearl millet in the Sahel, particularly in Niger (Youm, 1995), which has soilborne stages like the MHM.

\section{Materials and Methods}

\subsection{Impact of millet crop residue management}

In 2010, at both Sadore and at the Doukoudoukou Seed Multiplication Center $\left(13^{\circ} 51^{\prime} 0^{\prime \prime} \mathrm{N}, 6^{\circ} 19^{\prime} 60^{\prime \prime} \mathrm{E}\right)$, a trial was conducted to assess the impact of millet crop residue management on the survival of the MSB and other insect pests of pearl millet and their impact. The pearl millet cultivar used was ICMV IS 99001.

There were five treatments with four replications using a randomized complete block design: (1) millet stems exported at harvest; (2) millet stems left standing from harvest all through the dry season; (3) millet stems flattened toward the end of the dry season (four months after harvest); (4) millet stems flattened in the middle of the dry season (two months after harvest); (5) millet stems flattened at harvest). The experimental millet plots were $12.8 \mathrm{~m} \times 12.8 \mathrm{~m}$ (spacing of $0.80 \mathrm{~m} \times 0.40 \mathrm{~m}$, at ca $6-8$ seeds per hill, namely ca $3.5 \mathrm{~kg} / \mathrm{ha}$ ). Superphosphate (ca. $18 \% \mathrm{P}_{2} \mathrm{O}_{5}$ ) was broadcast at the rate of $200 \mathrm{~kg} / \mathrm{ha}$. This fertilization was based on the expected deficit in phosphorous in the Sadore plot used for this trial, which had been under fallow (and thus not fertilized), at least for the 25 years of existence of the ICRISAT station.

Two $1 \mathrm{~m}^{2}$ quadrats were harvested and the extent of MSB (counts of larvae per stem), of MHM (counts of mines per spike) and of MHS (counts of damaged spikes) were assessed. All aboveand below-ground macrofauna (including soilborne stages of MHM and MHS, i.e. pupae and white grubs, respectively) were sampled on the same quadrats, using a method derived from TSBF (Anderson and Ingram, 1993), down to $30 \mathrm{~cm}$ depth (which generally corresponded to the compaction surface), as described in Ratnadass et al. (2013). They were counted and weighed according to taxa. Grain harvested in these quadrats was also weighed, along with that of the rest of the plot, and yield per ha calculated. At millet harvest, soil samples were taken using a $5 \mathrm{~cm}$-diameter cylinder, from the surface $(0-$ to $15-\mathrm{cm})$ layer at the center and in each half diagonal of each plot. The five $0.295 \mathrm{~L}$-samples were pooled and reduced to a manageable sample by coning and quartering. Analyses were performed by ICRISAT's Soil Laboratory at Sadore: $\mathrm{pH}-\mathrm{H}_{2} \mathrm{O}$ and $\mathrm{pH}-\mathrm{KCl}$ (1:2.5); organic $C(\%)$; total $N\left(\mathrm{mg} \mathrm{kg}^{-1}\right)$; Bray-P1 ( $\left.\mathrm{mg} \mathrm{P} \mathrm{kg}^{-1}\right)$; ECEC $\left(\mathrm{cmol}^{+} \mathrm{kg}^{-1}\right)$.

At the end of the dry season (in May 2011), after all treatments had been applied, MSB survival was assessed on another two $1 \mathrm{~m}^{2}$ quadrats per plot, and above- and below-ground macrofauna were similarly sampled, counted and weighed.

\subsection{Data analysis}

Data were analyzed using the ANOVA module of XLSTAT (Addinsoft, 2011), after square root transformation for macrofauna counts, followed by mean comparison using Newman-Keuls method.

\section{Results}

At both Sadore and Doukoudoukou, soil compositions were homogeneous, with soil at Sadore characterized by a very low phosphorus content, and that of Doukoudoukou by very low carbon and nitrogen contents (Table 1 ).

Grain yield at the 2010 harvest was homogeneous at both locations, whereas MSB and MHM impacts were high and homogeneous at Sadore, but lower and more heterogeneous at Doukoudoukou. On

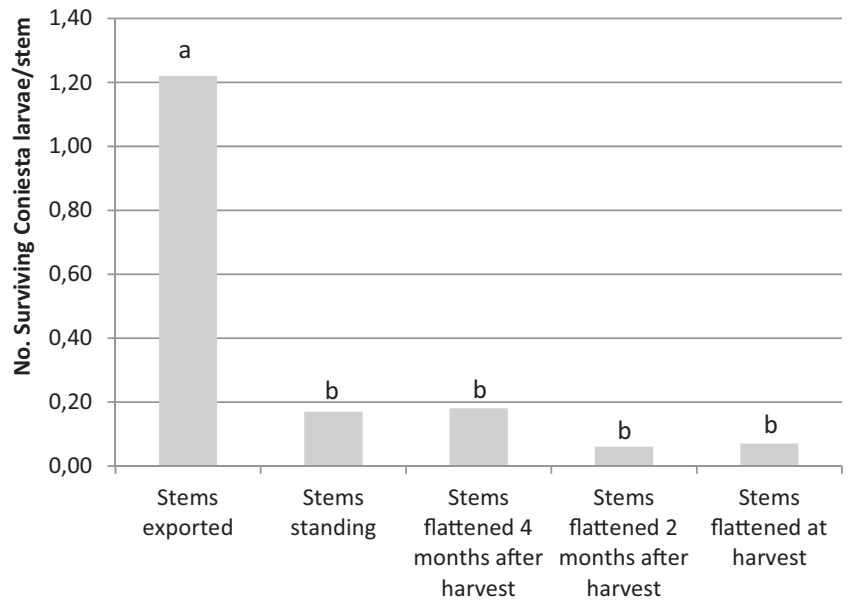

Fig. 1. MSB (Coniesta) survival in millet stems recorded at Sadore at the end of the dry season (May 2011). Bars with the same letters are not significantly different at $P<0.05$ according to Newman-Keuls test.

the other hand, the extent of millet head damage by MHS was high at both locations, although higher at Doukoudoukou (Table 2). Significant differences were found in the extent of MSB (diapausing) larval survival in millet stems at the end of the dry season at both locations (Figs. 1 and 2).

At Sadore, mean survival of MSB larvae in exported stems stored on platforms (treatment 1 ) was 1.2 /stem, significantly higher than in all other treatments. It was between 0.1 and 0.2 larva in treatments 2 (with millet stems left standing from harvest throughout the dry season) and 3 (with millet stems flattened toward the end of the dry season, four months after harvest). It was less than 0.1 larva in treatments 4 (with millet stems flattened in the middle of the dry season, two months after harvest) and 5 (with millet stems flattened at the beginning of the dry season, at harvest).

At Doukoudoukou, mean survival of MSB larvae in exported stems stored on platforms (treatment 1 ) was almost tenfold lower than at Sadore. It was 0.14 larva/stem, i.e. significantly higher than in treatments 4 and 5 (0.02-0.03 larva), whereas intermediary results were obtained in treatments 2 and 3 (0.04-0.08 larva), i.e. not significantly different from treatment 1 on the one hand, or from treatments 4 and 5 on the other.

Meanwhile, despite the high MHM numbers at harvest at Sadore, the population (Table A) and biomass (data not shown) of diapausing soilborne MHM pupae were low, although slightly higher than at Doukoudoukou (Table A). The same trend was observed for MHS larvae and millet head damage at Sadore, while at Doukoudoukou, slightly higher damage by MHS meant that there was higher soilborne MHS larval populations (Table A).

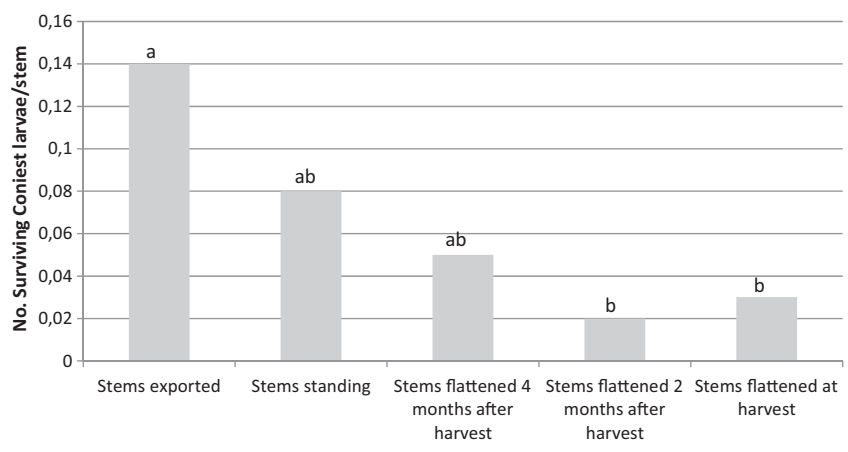

Fig. 2. MSB (Coniesta) survival in millet stems recorded at Doukoudoukou at the end of the dry season (May 2011). Bars with the same letters are not significantly different at $P<0.05$ according to Newman-Keuls test. 
Table 1

Results of soil sample analyses at Sadore and Doukoudoukou before the onset of the 2010 experiments.

\begin{tabular}{|c|c|c|c|c|c|c|}
\hline & $\mathrm{pH}-\mathrm{H}_{2} \mathrm{O}$ & $\mathrm{pH}-\mathrm{KCl}$ & Organic C (\%) & Total $N\left(\mathrm{mg} \mathrm{N} \mathrm{kg}^{-1}\right)$ & $\operatorname{ECEC~}\left(\mathrm{cmol}^{+} \mathrm{kg}^{-1}\right)$ & Bray-P1 (mg P kg $\left.{ }^{-1}\right)$ \\
\hline Sadore & $5.8 \pm 0.04$ & $4.2 \pm 0.06$ & $0.2 \pm 0.01$ & $183.3 \pm 8.24$ & $1.7 \pm 0.09$ & $4.2 \pm 0.38$ \\
\hline Doukoudoukou & $5.7 \pm 0.12$ & $4.7 \pm 0.04$ & $0.1 \pm 0.01$ & $100.8 \pm 6.48$ & $1.5 \pm 0.17$ & $11.4 \pm 1.80$ \\
\hline
\end{tabular}

Table 2

Grain yield and pest damage at Sadore and Doukoudoukou before the onset of the 2010 experiments.

\begin{tabular}{|c|c|c|c|c|}
\hline & Grain yield (kg/ha) & \% MSB bored stems & \% MHM damaged heads & \% MHS damaged heads \\
\hline Sadore & $1226.5 \pm 88.6$ & $66.3 \pm 7.8$ & $79.6 \pm 3.5$ & $62.8 \pm 9.8$ \\
\hline Doukoudoukou & $1176.3 \pm 225.3$ & $12.7 \pm 6.1$ & $1.9 \pm 2.3$ & $75.8 \pm 13.8$ \\
\hline
\end{tabular}

Supplementary material related to this article can be found, in the online version, at http://dx.doi.org/10.1016/j.agee.2014.01.021.

The major soil macrofauna groups (in terms of numbers) were Coleoptera, i.e. up to 28 individuals $/ \mathrm{m}^{2}$ at the first sampling at Sadore, with a majority being herbivores, including millet head pests MHS larvae, with up to 7.5 individuals $/ \mathrm{m}^{2}$ at the second sampling at Doukoudoukou. They were followed by termites and ants, with up to 19.2 and 9.5 individuals $/ \mathrm{m}^{2}$, respectively, at the first sampling at Sadore. Arachnids formed the main predator group, mainly hunting spiders and solifuges, with up to 3.9 and 1.9 individuals $/ \mathrm{m}^{2}$, respectively, at the second sampling at Doukoudoukou. Antlions (Neuroptera larvae) were also found in significant numbers. In addition, predatory ground beetles and tiger beetles were noted, although they were not separated from "other beetles", which included some herbivores (Table S1). The same was noted for bugs (Hemiptera), which included several predatory assassin bugs (Reduviidae). The same trends were observed in terms of biomass (data not shown).

Total macrofauna population, biomass nor any of the functional groups (including millet head pests) were affected by the crop residue management (Tables 3 and 4), except termite population and biomass at Doukoudoukou. Only for termite populations and biomasses at Doukoudoukou significant differences were found between the treatment where stems had been left standing and flattened four months after harvest on the one hand, and all other treatments on the other.

\section{Discussion}

Erosion-alleviating/fertility-improving management consisting of leaving millet stems standing until the end of the dry season with or without lodging them, did not result in increased control of millet head pests via increased predator activity.

Other studies reported the impact of other soil management techniques such as tillage (particularly deep ploughing) on the survival of diapausing pupae and carry-over of their populations (Vercambre, 1978; Nwanze et al., 1995).

However, leaving stems standing resulted in increased MSB survival, and potential carry-over, as compared to stem lodging at harvest or two months postharvest. Although the "activity" of termites per se was not measured, differences noted in MSB survival, particularly at Doukoudoukou, might be explained by the differential activity of termites, which probably peaked in each treatment at the moment when stems were flattened, at two-monthly intervals from harvest to the end of the dry season, when the last stems of the last treatment were flattened by winds.

The highest MSB survival was noted in exported stems stored on platforms. However, exporting stems and using them as fodder would likely result in reduced carry-over. Similarly, if stems are used for building material, techniques such as superficial burning-which was found to be effective against diapausing larvae of Busseola fusca, another cereal stem borer species, in sorghum stems (Adesiyun and Ajayi, 1980)-could also reduce MSB survival and carry-over.

Table 3

Macrofauna biota populations (no/m²) at Sadore (2nd sampling, May 2011).

\begin{tabular}{|c|c|c|c|c|c|c|c|}
\hline Treatment & Total & Heliocheilus & Herbivores & Rhinyptia & Termites & Predators & Spiders \\
\hline Stems exported & 20.6 & 0.9 & 6.6 & 2.0 & 12.0 & 1.0 & 0.1 \\
\hline Stems standing & 37.5 & 0.8 & 11.9 & 0.9 & 0.6 & 4.0 & 1.3 \\
\hline Stems flattened 4 months after harvest & 11.3 & 0.6 & 9.4 & 2.8 & 0 & 1.1 & 0.3 \\
\hline Stems flattened 2 months after harvest & 23.1 & 0.3 & 12.4 & 0.1 & 1.0 & 2.0 & 1.0 \\
\hline Stems flattened at harvest & 10.4 & 0.4 & 6.6 & 0.3 & 0 & 2.1 & 0.9 \\
\hline$P(F$-test $)$ & 0.256 & 0.660 & 0.556 & 0.159 & 0.577 & 0.170 & 0.176 \\
\hline
\end{tabular}

Table 4

Macrofauna biota populations ( $\mathrm{no} / \mathrm{m}^{2}$ ) at Doukoudoukou (2nd sampling, May 2011).

\begin{tabular}{|c|c|c|c|c|c|c|c|}
\hline Treatment & Total & Heliocheilus & Herbivores & Rhinyptia & Termites & Predators & Spider \\
\hline Stems exported & 24.9 & 0 & 10.1 & 6.8 & 0.6 & 3.1 & 2.6 \\
\hline Stems standing & 26.6 & 0.2 & 11.1 & 8.4 & 0.5 & 6.9 & 5.6 \\
\hline Stems flattened 4 months after harvest & 21.8 & 0.5 & 6.8 & 4.5 & 3.0 & 6.8 & 3.9 \\
\hline Stems flattened 2 months after harvest & 25.5 & 0 & 13.4 & 9.3 & 0.1 & 7.0 & 4.0 \\
\hline Stems flattened at harvest & 32 & 0.1 & 12.4 & 8.4 & 1.3 & 4.8 & 4.4 \\
\hline$P(F$-test $)$ & 0.898 & 0.272 & 0.602 & 0.779 & 0.003 & 0.695 & 0.718 \\
\hline
\end{tabular}


Furthermore, it is hard to convince farmers leave millet stems standing in the field during the dry season because they are grazed by wandering cattle, from which farmers obtain in return organic manure. Hence, despite encouraging results obtained in terms of erosion alleviation (Michels et al., 1998), this recommendation might be hard to actually implement. Furthermore, in current Sahelian farming systems, mulching competes with traditional crop residue uses (building material for granaries, fences or mats, or fuel for cooking) when land is limited (Harris, 1962; Lamers and Feil, 1993). Due to high crop residue opportunity costs, farmers may sell this residue to increase their present income, although these uses results in soil fertility depletion.

On the other hand, millet head pests, particularly the MHM, are more damaging than the MSB, since their action takes place when no compensation of the pest attack by the plant is possible, while MSB attack does not necessarily result in yield loss, due to compensation processes, and even overcompensation in some cases (Youm et al., 1996).

\section{Acknowledgements}

These studies were funded by the Bill \& Melinda Gates Foundation (BMGF), as part of the "HOPE for Dryland Cereals" project, and by ICRISAT and CIRAD core-budgets. We are grateful for the technical and administrative support from the Director of National Agricultural Extension Service in Niamey, the Regional Director for Agricultural Extension at Tahoua, the Director of INRAN/CERRA Tahoua and the Head of INRAN Konni research station for making the arrangements to conduct the field experiments at the Doudoudoukou Seed Multiplication Center. We also thank D. Manley for English revision.

\section{References}

Addinsoft, 2011. XLSTAT Version 2011.4.02. http://www.xlstat.com

Adesiyun, A.A., Ajayi, O., 1980. Control of the sorghum stem borer. Busseola fusca, by partial burning of the stalks. Trop. Pest Manage. 26, 113-117.
Ajayi, O., 1990. Possibilities for integrated control of the millet stem borer. Acigona ignefusalis Hampson (Lepidoptera: Pyralidae) in Nigeria. Insect Sci. Appl. 11, 109-117.

Anderson, J.M., Ingram, J., 1993. Tropical Soil Biology and Fertility. A Handbook of Methods, second ed. CAB International, Wallingford (UK).

Bielders, C., Rajot, J.L., Michels, K., 2004. L'érosion éolienne dans le Sahel nigérien: influence des pratiques culturales actuelles et méthodes de lutte. Sécheresse 15, 19-32.

Bouchard, D., Ouedraogo, A., Boivin, G., 1993. Impact de la coupe des tiges sur les larves diapausantes de Coniesta (= Acigona) ignefusalis (Lepidoptera: Pyralidae) Insect Sci. Appl. 14, 31-37.

Harris, K.M., 1962. Lepidopterous stem borers of cereals in Nigeria. Bull. Entomol. Res. 53, 139-171.

Lamers, J.P.A., Feil, P., 1993. The many uses of millet residues. ILEA Newslett. 9, 15.

Michels, K., Lamers, J.P.A., Buerkert, A., 1998. Effects of windbreak species and mulching on wind erosion and millet yield in the Sahel. Exp. Agric. 34 449-464.

Millennium Ecosystem Assessment, 2003. Ecosystems and Human Well-Being: A Framework for Assessment. Island Press, Washington, DC.

Nwanze, K.F., Klaij, M.C., Markham, R.H., 1995. Possibilities for integrated management of millet earhead caterpillar, Heliocheilus albipunctella. In: Nwanze, K.F. Youm, O. (Eds.), Panicle Insect Pests of Sorghum and Pearl Millet: Proceedings of an International Consultative Workshop, 4-7 October 1993, ICRISAT Sahelian Center, Niamey, Niger. ICRISAT, Patancheru, pp. 263-271.

Rajot, J.L., Karambiri, H., Ribolzi, O., Planchon, O., Thiebaux, J.P., 2009. Interaction entre érosions hydrique et éolienne sur sols sableux pâturés au Sahel: cas du bassin-versant de Katchari au nord du Burkina Faso. Sécheresse 20 131-138.

Ratnadass, A., Randriamanantsoa, R., Rajaonera, T.E., Rabearisoa, M., Rafamatanantsoa, E., Moussa, N., Michellon, R., 2013. Interaction entre le système de culture et le statut (ravageur ou auxiliaire) des vers blancs (Coleoptera: Scarabeoidea) sur le riz pluvial. Interaction between cropping systems and white grub (Coleoptera: Scarabeoidea) status (pest or beneficial) on upland rice. Cah. Agric. 22, 432-441.

Renard, C., Vandenbelt, R.J., 1990. Bordures d'Andropogon gayanus Kunth comme moyen de lutte contre l'érosion éolienne au Sahel. Agron. Trop. 45, $227-231$.

Vercambre, B., 1978. Raghuva spp. et Masalia sp., chenilles des chandelles de mil en zone sahélienne. Agron. Trop. 33, 62-79.

Youm, O., 1995. Bioecology of scarab beetle Rhinyptia infuscata and millet head miner Heliocheilus albipunctella. In: Nwanze, K.F., Youm, O. (Eds.), Panicle Insect Pests of Sorghum and Pearl Millet: Proceedings of an International Consultative Workshop, 4-7 Oct 1993, ICRISAT Sahelian Center, Niamey, Niger. ICRISAT, Patancheru, pp. 115-124.

Youm, O., Harris, K.M., Nwanze, K.F., 1996. Coniesta ignefusalis (Hampson), the Millet Stem Borer: a Handbook of Information, Information Bulletin no. 46. ICRISAT, Patancheru. 